\title{
Strategic resources of the developer organizations after the change of legislation on the shared construction
}

\author{
Tamara Svetnik ${ }^{1, *}$ \\ ${ }^{1}$ Baikal State University, 664003, Lenin str., 11, Irkutsk, Russia
}

\begin{abstract}
An important and very significant for the construction industry issue is under discussion in this paper - possible losses of the strategic development resources that will arise as a result of the unsystematic solution of the problem of shareholders. It is shown that in the near future, due to the key importance of the construction industry in the development of the country and the difficulties that have arisen in its activities, it will be necessary to search for the appropriate solutions. At present, the attention of theorists and practitioners is directed solely at the consideration of the consequences of legislative changes for citizens and developers organizations. With the use of the I. Ansoff's methodology, the need for the strategic management in the construction industry has been confirmed, and instability of the external environment for the construction organizations of the Irkutsk region at the end of 2017 and the expected turbulence from the middle of 2018 after the introduction of the adopted legislative changes and new rules of the game on the housing construction market has been expertly assessed. The strategic resources of the industry are singled out, and it is considered how the introduced changes affect their reduction in the near future. It is concluded that the measures proposed by the legislators are not aimed at solving the strategic problems of the industry, but at the expense of excommunication of developers from money and other strategic resources exacerbate the situation. The proposals on the systemic adjustment of the adopted laws are considered in the paper.
\end{abstract}

The future cancellation of the equity financing, caused by a large number of defrauded coinvestors across the country, is actively discussed in scientific and business literature. The issue is considered both from the positions of citizens affected by the activities of unscrupulous builders $[1,2]$, and taking into account the interests of developer organizations, the consequences of changes in the legislation for which will be very significant [3-5]. The introduction of the project financing that is planned in three years will radically change the mechanism of their activity [14].

In this article we discuss the important and very significant issue for the construction industry - the issue of possible losses of strategic development resources that will arise as a result of the unsystematic solution of the problem of shareholders. While researchers have not paid attention to this situation, in our opinion, due to the key significance of the

*Corresponding author: svetnikt@mail.ru 
construction industry in the development of the country and difficulties that have arisen in its activity, it will soon become necessary to find appropriate solutions. The purpose of this article is to consider the strategic resources of developer organizations and their possible losses as a result of changes in the legislation on the shared construction.

The effectiveness of the strategic approach to the development of organizations of all sectors was proved yet at the end of the $20^{\text {th }}$ century by I. Ansoff [6]. Using his methods [6, p. 17-18] to confirm the need for strategic management in the construction industry, we expertly assessed instability of the external environment for the construction organizations of the Irkutsk region at the end of 2017, and the expected turbulence from the middle of 2018 due to the introduction of the adopted legislative changes and new rules of the game on the housing construction market (Figure 1). These are the amendments to the well-known Federal Law No. 214-FZ and the adoption of the Federal Law No. 218-FZ of 29 July 2017 "On the Public-Legal Company for the Protection of the Rights of Citizen-Participants in the Shared Construction from Insolvency (Bankruptcy) of Developers and Amendments to Certain Legislative Acts of the Russian Federation" (hereinafter - the Law No. 218-FZ). The study takes into account the expert opinions of 59 managers of different levels and owners of the contract organizations. The results obtained are shown in the Table 1.

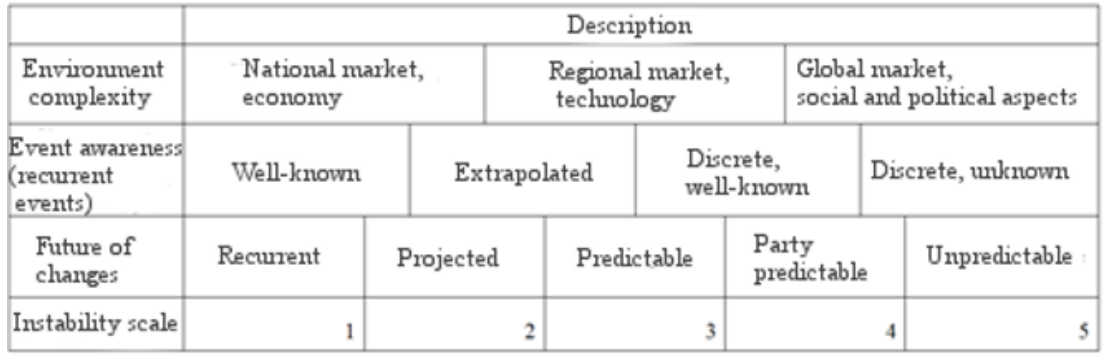

Fig. 1. The scale of instability of the environment.

Table 1 The expert assessment of instability of the environment for the construction organizations in the Irkutsk region.

\begin{tabular}{|l|c|c|}
\hline $\begin{array}{c}\text { Environment } \\
\text { characteristics }\end{array}$ & $\begin{array}{c}\text { Environment instability } \\
\text { at the end of } 2017\end{array}$ & $\begin{array}{c}\text { Expected environment } \\
\text { instability from mid-2018 }\end{array}$ \\
\hline Market complexity & 2.5 & 2.5 \\
\hline Repeatability of events & 2.7 & 4.0 \\
\hline Future predictability & 3.3 & 4.5 \\
\hline Average & $(2.5+3.0+3.5) / 3=2.83$ & $(2.5+3.5+4.5) / 3=3.67$ \\
\hline
\end{tabular}

The results of the assessment, presented in the Table 1, indicate that changes will become rapid, and the environment of organizations will become more complex due to the legislative changes and new rules of the game. If at the end of 2017, it was believed that the future of developers depended on the past experience by $43.4 \%$, since the mid-2018 - only by $26.6 \%$. Many legal procedures have not been worked out yet, laws are contradictory, legislators do not make scenario planning of the consequences of their application (scenario planning is a method of identification of the basic direction of changes in the state of an object by fixing alternatives).

In the situation of increasingly complex external environment, in order to survive contractors need deep and good understanding of the dynamics of development of the construction market. Identification of the external environment issues and enhancement of the company's internal strengths for the purpose of seeking opportunities are the basic strategies necessary to achieve sustainable growth [7, p. 63]. 
According to the definition of the Russian methodologist P.G. Shchedrovitskii, strategy is a high-level managerial document that is associated with the resource maneuvering. Strategy is the art of concentrating resources. The organization should have free resources, which it is ready to concentrate on the strategic directions. If they do not exist, then there is no possibility of having a strategy [8]. With the accumulation of experience in developing strategies, organizations will have the opportunity to set more and more complex strategic goals. For example, in Brazil, in earlier strategies, goals were simplified. In 1994, the company Latham called for $30 \%$ increase in efficiency over five years, and the company Egan in 1998 set the annual decrease in the cost and time indicators by $10 \%$. Until now, simple goals remain $(20 \%)$, but now organizations are more and more using strategies to increase productivity by better efficiency and eliminating waste, improving the procurement system, integrated design, building information modeling, and improving business processes, project management and innovation in construction [9].

As strategic resources, we understand the means to solve strategic issues, as well as the opportunities that can be used for a long time and that are available to the organization. Let us highlight the main strategic resources of the developer organizations:

- Tangible resources - finance and land.

- Intangible resources - time and culture of activity.

These resources are interrelated and interdependent, and we will consider them in unity. The availability of solvent demand from the state, the corporate sector and the population is a necessary condition for their use. According to the Center for Market Research of the Institute for Statistical Studies and Knowledge Economy of the National Research University "The Higher School of Economics", 56\% of the executives surveyed named a shortage of demand, characterized by a lack of orders and insolvency of customers, the main factor constraining the development of the housing market [16]. The importance of the supply and demand factors on the local market of industrial construction in the process of shaping strategy for balancing development of the regional economics is being addressed by other authors [10].

The availability of own land bank is an evidence that the developer has come to the market seriously and for a long time. The land bank contributes to its financial stability, since, if necessary, it is possible to use funds from the sale of plots not only for the implementation of new projects, but also for securing or repaying loans. Ideal is the option, when at the end of the implementation of a project, the next one is already under construction, sale of apartments is ongoing, and another one or two are being designed. But according to the conditions proposed by the legislators, the rules for the development of land plots are changing. If the plots are located throughout the city, the developer must create a separate company for each project, for which it is necessary to obtain a permit that is possible with a three-year experience in the construction industry with at least 10,000 square meters. In their absence, the developer will create just one project in three years. The remaining land plots will be idle, sold, or returned to the state. As a result, project financing can become a way for the new quick and cheap expropriation of land [11]. Only large developers, having the support of the state, will not go to bankruptcy in such conditions. The result will be a monopoly of the market, the withdrawal of medium and small organizations from it. New participants on the market will not be able to appear because of the lack of three years of experience in the construction of apartment building with a total area of at least 10,000 square meters in the aggregate.

The new requirement is the minimum amount of the charter capital of the contractor, providing for the availability of its own funds, the amount of which should be at least $10 \%$ of the planned project cost of the construction. At the date of submission of the project declaration to the authorized body of the executive authority of the constituent entity of the Russian Federation that exercises the state control (supervision) in the field of the shared 
construction, the developer's own funds in the amount not less than the amount established by the Law shall be available on its bank account. The developer must have the entire package of documents, including a construction permit. Project financing is provided with full project documentation, the construction permit, and at least $30 \%$ of funds invested in the site under development. The developer should not have loan commitments and loans, with the exception of the targeted loans related to the acquisition of the equity holders' funds. These requirements are almost impossible to fulfill. They will hit small and medium-sized companies and eventually lead to the enlargement of the market.

From July 1, 2018, the developer has the right to have only one settlement account (settlement account of the developer) in the authorized bank, through which all settlements for construction of the equity object should be performed. The technical customer and the general contractor, performing work in accordance with the agreement concluded with the developer, are also required to open a bank account in the same authorized bank and make settlements between themselves only with the use of the specified accounts. Banks are entrusted with special functions for exercising control over operations on these accounts. Banks that will carry out lending to developers have the right to independently establish criteria for evaluating developers and funded projects, and for monitoring the use of the credit resources in the contracts.

Additional burden on the developers and banks in connection with the introduction of a new order will significantly increase. Substantial expansion of the powers of banks leads to an increase in their pressure on the developers. The amendments offer regulation measures that do not solve the tasks to eliminate deceived buyers-participants of the shared construction posed by the state, but create additional burdens for business, which will lead to unnecessary costs for the buyers of housing and for all market participants.

Escrow accounts as a new guarantee for the shareholders are entered. They keep the means of the shareholders (co-investors) before certain circumstances or obligations would have happened. It means that the bank that gives the developer a loan for the construction of real estate can set him a condition - to open an escrow account in this bank. A shareholder who buys an apartment from a developer will not transfer money to him, but to an escrow account in the bank. The construction company will receive this money within 10 days after the signing of the act of transfer and acceptance of the apartment with the shareholder only. If, for some reason, the developer would not have completed the construction, the shareholder will receive his money back from the bank.

In Russia, escrow accounts are already used. According to forecasts, the share of contracts with their use by the middle of 2019 may amount to about $30 \%$ of the total number of registered contracts for the participation of the shared construction. Now their use is a voluntary measure and is not in high demand. When it becomes mandatory, the developers will incur losses, which will be included in the cost of a square meter. For banks, escrow accounts can be one of the sources of funding loans to developers. In order to make the project financing working, a loan must be cheap and long-term. As long as the development organizations receive expensive loans (up to $20 \%$ per annum for large loans, and from $25 \%$ for medium and small loans), the transition to the project financing will lead to a significant rise in the cost of housing.

But whether the state and banks are ready to do this is not yet known. According to the assessment of the head of the Ministry of Construction of the Russian Federation M. Men, at present private investments in the construction of residential real estate are about 3.5 trillion rubles. It is important to get a response from the banking sector: for how long and at what price of money will banks be able to replace these 3.5 trillion rubles. Is this amount of funding available to the banking system? And if so, for what period? [16]. Will they be able to compensate the means of the shareholders so as to maintain the pace of construction? 
In Germany, for example, there is also a shared construction, but there is a possibility of the staged spending of the shareholders' funds. The key proposal is to allow the developer to spend the shareholders' funds from the escrow account in an authorized bank according to the following scheme (Table 2).

Table 2. Stages of spending of the shareholders' funds from the escrow account by the developer [2].

\begin{tabular}{|l|l|c|}
\hline \multicolumn{2}{|c|}{ Stage } & $\begin{array}{c}\text { Amount of the expenditure } \\
\text { (from the price of the } \\
\text { equity participation } \\
\text { agreement) }\end{array}$ \\
\hline 1 & Construction permit (advance payment) & $10 \%$ \\
\hline 2 & Zero cycle & $20 \%$ \\
\hline 3 & Readiness 50\% of the frame of the building & $20 \%$ \\
\hline 4 & Readiness 100\% of the frame of the building & $20 \%$ \\
\hline 5 & Closing the heating circuit of the building & $10 \%$ \\
\hline 6 & Permission to put the object in operation & $10 \%$ \\
\hline 7 & $\begin{array}{l}\text { Transfer of the shared construction object to the share } \\
\text { building participant under the acceptance certificate }\end{array}$ & $10 \%$ \\
\hline
\end{tabular}

Time as a strategic resource is no less important than money, information, technology, personnel and other factors. It is possible to "accelerate", "slow down", "accumulate" and "arrange" time. The requirement "one object - one authorization for construction" slows down time. Moreover, it is unclear who will build the infrastructure, if a number of houses in the neighborhood are built by different developers. With introduction of the new requirements, the situation will become more difficult not only for the developers, but also for the city. The work of the project "Development of the built-up areas" will be stalled, it will be impossible to build social and engineering facilities outside the sites in the framework of the equity participation agreements. How to preserve the possibility of working on the development of the built-up areas? Now, the shared construction allows developers to help the state by participating in the implementation of the programs of provision apartments to orphans, and resettlement from dilapidated and emergency housing. The impossibility to work on these programs will not allow solving the most important strategic tasks.

Abroad (in Germany, France, Spain, Great Britain, and Italy) they go the other way. The construction of social facilities is often carried out with the help of socially responsible investments, formed on the basis of principles of financing and ethics. The spread of the ethical investment grew moderately until the early 2000s, and then quickly increased as a result of the global financial crisis. Thanks to the development of corporate social responsibility and the full awareness of investors, these funds cannot be spent inappropriately. The interaction of participants in the construction process is based on the combination of long-term profit for investors and the benefits to the society, benefits for different categories of stakeholders [12, 17].

We can draw a general conclusion: the presence of defrauded shareholders (co-investors) is the result of the inadequate construction financing. Even conscientious builders may have problems, such as low sales and delays with lending. But the law does not allow companies to take targeted loans and loans from the participants and shareholders, although this would ensure compliance with the terms of construction, and, accordingly, protect the rights of participants in the shared construction.

The low solvency of the population, which unfair developers used, and financially weak organizations that became hostages, exacerbate the problem. The measures proposed by the legislators are aimed not at resolving the strategic problems of construction, but at restraining 
it by excommunicating the developers from money and other important resources. The remaining time must be used to adjust the adopted laws.

\section{References}

1. T. I. Kubasova, N. G. Novikova, A. P. Sukhodolov, Baikal Research Journal, 8(4) (2017)

2. A. Kirsanov, Unified register of developers (https://erzrf.ru/news/andrey-kirsanovklub-investorov-moskvy-yeshche-ne-pozdno-skorrektirovat-v-214-fz-trebovaniya-nesoglasovannyye-drug-s-drugom, 2018)

3. O. Vysotsky, Unified register of developers (https://erzrf.ru/news/oleg-vysotskiy-smpro-v-blizhayshiye-dva-tri-goda-vvod-zhilya-mozhet-yezhegodno-sokrashchatsya-na10, 2018)

4. T. V. Svetnik, Baikal Research Journal, 8(4) (2017)

5. A. Markova, IA “Irkutsk online” (http://www.irk.ru/news / articles / 20180108 / building, 2018)

6. I. Ansoff, New corporate strategy (Peter Kom, St. Petersburg, 1999)

7. H. Setiawan, B. Erdogan, S. O. Ogunlana, H. Setiawan, Civil Engineering Innovation for a Sustainable Development, 125 (2015)

8. P. G. Shedrovitsky, Institute of Education Development of the Irkutsk (http://www.iro38.ru/files/FROS/tutor-servis/22-11-

16/Petr_Shchedrovitckii_Strategichnost_upravleniia-mif_ili_realnost.pdf, 2018)

9. A. A. R. Barbosa, M. Vilnītis, IOP Conference Series-Materials Science and Engineering, 251 (2017).

10. V. I. Samarukha, T. G. Krasnova, A. S. Wilhelm, Baikal Research Journal, 9(1) (2018).

11. V. Yakhontov, Vedomost (https://www.vedomosti.ru/realty/blogs/2018/01/26/74907proektnoe-finansirovanie-stroitelstva-zhilya)

12. F. Battisti, M. R. Guarini, A. Chiovitti, Sustainability, 9(6), 973 (2017).

13. M. Y. Veselovsky, M. A. Izmailova, A. V. Bogoviz, S. V. Lobova, A. N. Alekseev, Quality - Access to Success, 19(162), 60-66 (2018)

14. Reform: protecting the "deceived" or "cutting fat cats"? (http://sia.ru/?section $=484 \&$ action= how_news $\&$ id $=351590$ )

15. What factors limit the activity of construction organizations: the opinion of experts (https://erzrf.ru/news/kakiye-faktory-ogranichivayut-deyatelnost-stroitelnykhorganizatsiy-mneniye-ekspertov)

16. Banks instead of DDU: how the new scheme of housing sales will change the market of new buildings (https://realty.rbc.ru/news/5a01cf9a9a794735447205df)

17. Y. V. Ragulina, A. V. Bogoviz, A. N. Alekseev, Advances in Intelligent Systems and Computing, 622, 568-573 (2018) 